\title{
Effect of Social Assistance Programmes on Improving Quality of Life in Kenya: Evidence from Machakos County
}

\author{
Joshua Mutambu Ngelu (MA) \\ College of Human Resource Development \\ Jomo Kenyatta University of Agriculture and Technology, Kenya
}

doi: 10.19044/esj.2017.v13n20p124 URL:http://dx.doi.org/10.19044/esj.2017.v13n20p124

\begin{abstract}
This study investigates the effect of social assistance programmes on improving quality of life in Kenya - evidence from Machakos County. Probit model was applied to model the empirical analysis. The paper concludes that moderate households' awareness of available types of cash transfer. On the households' quality of life with reference to social assistance programmes, the study posits that households in receipt of bursary support, cash transfers for orphans and vulnerable children, and cash transfers to the elderly will report an improved life quality compared to their counterparts who have not received such transfers. Similar conclusion is arrived at for remittances receipts from relatives residing outside the County. The paper recommends application and scaling up of social assistance programmes to reduce poverty at county and national levels so that in turn can improve quality of life of households. This will go a long way in achieving the Sustainable Development Goals.
\end{abstract}

Keywords: Social assistance programmes, Cash transfers and Probit model

\section{Introduction}

Social assistance programmes are increasingly becoming a cornerstone of anti-poverty efforts in many developing countries (Heinrich, 2007; de la Briere and Rawlings, 2006). One such programme is in form of cash transfers both as conditional and the unconditional support. Cash transfers are policies and actions which enhance the capacity of poor and vulnerable people to escape from poverty and better manage risks and shocks (Organisation for Economic Cooperation and Development, 2009). As such cash transfers are generally seen as one of the main instruments for delivering social assistance in the recent decade. Therefore, the role of social assistance mechanisms is that of policy tools to tackle poverty, vulnerability 
and social exclusion is understated (Barrientos \& DeJong, 2006; Marcus 2006; UNDP 2006). In Europe and North America, poverty reduction efforts through social assistance programmes begun after the Second World War and subsequently spread to Latin America and lately in the other continents.

De Janvry, Sadoulet, and Vakis (2008), asserts that in the short-term, social assistance programmes serve as a social safety net that assists the chronic poor and vulnerable segments of the population in adjusting and coping with negative effects of various forms of shocks. By supporting income levels, these programmes ensure that poor families meet their immediate basic consumption needs (de la Briere and Rawlings 2006). Further, (Samson et al, 2004) is of conclusion that for the households receiving Old Age Pension in South Africa, their labour force participation is higher by $11 \%$ to $12 \%$ compared to the households who do not receive such cash transfers. Similarly, In Swaziland the prospect of a guaranteed income through the Old Age Grant provides access to farm inputs on easy (concessionary) terms, and particularly through agricultural cooperatives and credit unions (Dlamini, 2007). In addition, (HelpAge, 2006) points out that in Lesotho, Old Age Pension leads to an average of $18 \%$ of the money being transferred towards creating jobs for other people.

These programmes also aim to improve the health, nutrition, and education of young children in the short term and their income earning potential in the long-run, ultimately disrupting the intergenerational transmission of poverty. However, (Enrique, 2008), notes that the overall consensus is that, in the short term, these programmes are more successful in decreasing the intensity of poverty than in lowering overall incidence. Ideal case studies on the effectiveness cash transfers as a form of social assistance programme in improving the livelihood of the beneficiaries can be traced in the larger Latin America countries with Mexico leading in the number of the case studies. In the case of Mexico, 30\% of beneficiaries of cash transfer programmes experienced a decline in income poverty, according to Nigenda and González-Robledo (2005). Maluccio’s (2005) randomized evaluation of Social protection in Nicaragua revealed that among households affected by a coffee crisis, beneficiaries of the programme were able to maintain preprogramme expenditure levels, in contrast to a $22 \%$ decline among nonbeneficiary households in the same region.

In Kenya, the National Gender and Equality Commission (2008) posit that household empowerment is positively correlated with social assistance programmes. More particularly, the number of dependents a beneficiary of a social assistance programme has in their household is correlated with effectiveness and efficiency of the cash transfer program on empowerment at the household level. It can be pointed out that much of the 
existing literature relevant to the study is on global basis and a few isolated cases on national and regional basis. In 2000 the international community declared its commitment to the eradication of poverty as part of the Millennium Development Goals (MDGs) and later in 2016 among the Sustainable Development Goals (SDGs). At the regional level the African Union in 2013 launched Agenda 2063 as a “ call for action” to all segments of African society to work together to build a prosperous and united Africa (AU, 2013). It is in view of this Kenya Vision 2030 and the subsequent Medium term Plans has committed to reduce poverty in the country.

To support poor households the Government of Kenya has set up programmes aimed at enhancing social protection among the vulnerable groups. These programmes include; Orphans and Vulnerable Children Cash Transfer Programme, Older Persons Cash Transfer (OPCT), Persons with Severe Disabilities Cash Transfer Program (PWSD-CT). Other forms of social assistance programmes in existence include bursaries, school feeding programmes and hunger safety nets. However, even though these programmes have been in existence for more than a decade now, scanty empirical works in the Kenyan context are visible with regard to the performance of these programmes in improving the livelihood of the beneficiaries.

Kenya National Bureau of Statistics (KNBS), in its report of 2006, the Kenya Integrated Household Budget Survey (KIHBS), estimated the level of absolute poverty incidence at 45.9\%, while the absolute rural poverty stood at 49.1\% (Republic of Kenya, 2007). According to the 2009 Population and Housing Survey, Kenya has a population of over 38 million, $46 \%$ of whom live below the poverty line level of one dollar a day. Among these, 19 percent live in extreme poverty. Of the population 20.6 million people are aged below 18 years of age hence children comprising over 53\% of the total population (KNBS, 2010). It is estimated that 2.4 million children are orphans, with $2 \%$ of these children having lost both parents. Besides poverty, Kenya is also a very unequal country where the gap between the rich and the poor has continued to increase over time which is evidenced by high GINI coefficient hence the disparities between rural and urban areas, disparities in incomes and access to education, health and other basic needs like water, adequate housing and sanitation.

Since 2001 the Government of Kenya intensified its efforts to fight poverty as indicated by the policy documents such as the Poverty Reduction Strategy Paper (PRSP), (Republic of Kenya, 2001). The PRSP outlines priorities and strategies to be taken to reduce poverty in Kenya. The PRSP is therefore one of the strategies in the reduction of poverty as outlined in the National Poverty Eradication Plan, the UN Millennium Development Goals (MDGs) and 2030 Agenda, Sustainable Development Goals (SDP). 
Based on the PRSP Kenya prepared its Medium-Term Expenditure Framework (MTEF) budget system in 2001/2002, which aimed at improving the quality of expenditure by shifting resources towards pro-poor activities and programmes. In 2003/2004 Kenya developed its Medium-Term Plan which was called "Economic Recovery Strategy for Wealth and Employment Creation "(ERC) (Republic of Kenya, 2003). The ERC created the following pro-poor activities, first the free primary education, secondly the Constituency Development Fund (CDF), and thirdly the Local Authorities Transfer Fund (LATF). It can be noted that both CDF and LATF go directly to local levels, therefore providing the people at the grassroots the opportunity to access social assistance programmes.

Despite there being various poverty reduction strategies since independence, there has been a marked increase in the number of poor and vulnerable people in Kenya (Tegemeo, 2009). The hardest hit among these are children and the elderly. Owing to this realization, the Government of Kenya has intensified the fight against poverty through the implementation of the above poverty reduction strategies. The underpinning reason behind this is the understanding that social assistance intervention in developing countries to protect and promote the livelihoods of the vulnerable population is critical in reducing poverty levels significantly. This forms the purpose of investigating this study.

Machakos County is one of the 47 counties in Kenya with 10 Constituencies. The County has $59.6 \%$ of the population living below poverty line with $58 \%$ and $27 \%$ of the population having attained primary and secondary levels of education respectively, while $17 \%$ and $32 \%$ of households are connected to electricity and clean drinking water respectively. It's clearly evident that poverty levels in the County are above the national poverty levels. Given this scenario, the study will investigate the effect of social assistance programmes in improving the quality of life in Machakos County. Machakos County is not unique from other counties in Kenya and faces similar challenges as those faced by other counties. Therefore the findings will inform the policy-makers at both the national and county level towards the realization of the poverty reduction agenda.

\section{Overview of Cash transfer programmes in Kenya}

Cash transfer programmes form a crucial portion of social assistance programmes and often are concerned with social insurance and social protection targeting a number of different vulnerable groups in the form of conditional and unconditional cash transfers and income supplements in cash or kind. Cash transfer is one of the major social assistance programmes 
geared towards offering social protection of the vulnerable groups. In Kenya cash transfer programmes have been in place since year 2000 in Kenya.

\section{Older Persons Cash Transfer (OPCT)}

Kenya has made commitments to addressing issues of the elderly through national legal and policy frameworks. In 2010, a commitment to social protection was enshrined in Kenya's Constitution, and asserts the "right for every person to social security" and "binds the State to provide appropriate social security”. The OPCT was launched in 2006 at an annual government allocation of KSh. 4 Million. During the first arm of the pilot phase, the programme provided monthly cash transfer of KSh. 1,065 to 300 households with destitute elderly people in Nyando, Busia and Thika districts. The programme was expanded in 2009 receiving KSh. 550 million from the in 2009/2010 financial year and further to KSh. 1 billion in 2011/2012 financial year. The programme was allocated KSh. 1.5 billion in 2012/13 financial year and KSh. 3.2 billion in the 2013/14. It is envisaged that the programme will be scaled up to benefit more elderly and achieve a regional balance in the spirit of devolution. The programme targets old persons as people of age 60 or more years

\section{Cash Transfer for Orphans and Vulnerable Children (CT-OVC)}

The CT-OVC programme was launched in 2004 with broad objective of strengthening households' capacities to provide a social protection system through regular cash transfers to families with Orphans and Vulnerable Children (OVC) in order to encourage fostering and retention of (OVC) in their families within the communities and to promote their human capital development. CT-OVC is currently the largest CT programme in the country. Kenya has an estimated over 2.4 million orphans and vulnerable children half of which have resulted from death of parents due to HIV and AIDS epidemic. Kenya's CT-OVC programme started as a pre-pilot project covering 500 OVC households in three districts (Kisumu, Garissa, and Kwale). The national policy on orphans and vulnerable children developed in 2005 is one of the earliest policy frameworks that grounded in the CT-OVC programme in the pilot and scale up phase.

By 2009, the funding to the programme increased to KSh. 900 million from KSh. 80 million allocated in 2005 and with coverage increased to 47districts. Every year since then, the programme has received increased budget allocations from the exchequer. The financial year 2011/2012 saw KSh.2.8 billion allocated to the programme rising to KSh. 4.4 billion in 2012/2013 and later to KSh 8 billion in 2013/2014. 


\section{Persons with Severe Disabilities Cash Transfer Program (PWSD-CT)}

The PWSD-CT is premised on the fact that disbursements of funds to PWD wishing to engage in entrepreneurial and/or obtain assistive devices may not be sufficient or useful to severe cases of disability. The programme is rolled out in all counties and former 210 constituencies and targets households with persons with disability; extremely poor households, nonrecipients of pension or reasonable regular income, and non-receipts of other cash transfer services. As at 2010, Kenya had an estimated 1.3 million persons with disabilities representing about 3.5\% of the total population (KNBS, 2010). At global level it is evident that PWD suffer disproportionately the effects of poverty and deprivation due to limited opportunities and enabling environment promoting self-independence and empowerment. During 2012/2013 financial year the programme received an enhanced budget of KSh. 385 million in 2012/2013 rising to KSh. 770 Million in 2013/2014 financial year thus demonstrating government commitment to increase coverage of the social welfare program for the vulnerable PWD.

\section{Foreign remittances}

In addition to the above cash transfers, migrant remittances have become an important source of income and foreign exchange for many developing countries. Buch and Kuckulenz (2002) point out that worker remittances constitute an increasingly important mechanism for the transfer of resources from developed to developing countries and are the secondlargest source, behind foreign direct investment, of external funding for developing countries. Ratha (2003) corroborates the point that migrants may increase remittances in times of economic hardship, especially in lowincome countries where their families live at close to subsistence levels may depend significantly on remittances as a source of income. Rural dwellers will therefore rely on the remittances from their relatives in major towns and others living abroad for meting their basic needs. In addition to these major cash transfer programmes, other forms of cash transfers in Kenya include the school feeding programmes, bursaries and hunger safety nets.

\section{Methodology}

\section{Theoretical framework}

\section{Theory on Absolute Poverty}

Todaro, \& Smith, (2011), define absolute poverty as a situation of being unable to meet the minimum level of income, food, clothing, healthcare, shelter and other essentials. Therefore, under the absolute poverty theory the assertion is that an individual lives below the poverty line. 
Looking at the theory on absolute poverty the argument would correspond to a situation where an individual would remain permanently or at least for a very long time, below some physical poverty line mainly being attributed to: First, the limited income mobility and secondly, slow economic growth making more distant the prospect for poor people to cross the poverty line.

Absolute poverty theory is however criticised for its failure to address the broader quality of life issues or with the overall level of inequality in society. As such it falls short of recognizing that individuals have important social and cultural needs which need to be met for their survival. As such, this criticism led to the development of the concept of relative poverty.

\section{Theory on extreme poverty}

Extreme poverty as amount of income one needs to satisfy the most basic needs (Hulme, et al, 2003). Therefore, extreme poverty covers absolute needs (food, shelter) plus health care, education and specific needs depending on where people live. Extreme poverty can therefore be generally referred to a poverty line. Extreme poverty is therefore the inability to meet basic consumption needs on a sustainable basis. People who live in extreme poverty lack both income and assets and typically suffer from interrelated, chronic deprivations, including hunger and malnutrition, poor health, limited education and marginalization or exclusion. Women and girls in particular face distinct challenges. From this perspective, it's evident that gender discrimination enters into the definition of extreme poverty. The extreme poor often face discrimination, marginalization or exclusion and are vulnerable to falling further into extreme poverty, lacking the resilience to cope with economic setbacks, natural disasters or illnesses. The study therefore relies on extreme poverty theory in modelling the effect of social assistance programmes on improvement of quality of life among Machakos County Households.

\section{Target population and Sample Size}

The study targeted the entire population of Machakos Town Council which currently 48,989 households distributed across 13 locations according to 2009 national census.

Combination of probabilistic and non-probabilistic sampling was applied in choosing the sample size. First the population was clustered into the administrative units implying that there are 13 clusters since MTC has 13 locations. Secondly, simple random sampling was then be applied to select the household to be interviewed. From the target population a sample size of 381 households using the formula:

$\mathrm{n}=\mathrm{N} * \mathrm{X} /(\mathrm{X}+\mathrm{N}-1)$,

Where, 
$\mathrm{X}=\mathrm{Z}_{\alpha / 2}^{2} * \mathrm{p} *(1-\mathrm{p}) / \mathrm{E}^{2}$,

$\mathrm{Z}_{\alpha / 2}$ is the critical value of the Normal distribution at $\alpha / 2$ (for a confidence level of $95 \%, \alpha$ is 0.05 and the critical value is 1.96), $\mathrm{E}$ is the margin of error, $\mathrm{p}$ is the sample proportion, and $\mathrm{N}$ is the population size. It should be noted that a Finite Population Correction has been applied to the sample size formula. The study applies 95\% confidence interval in selecting the sample implying that the $\mathrm{E}$ is $5 \%$.

Table 1: Target population

\begin{tabular}{cc}
\hline Name of Location & No. of households \\
\hline Township & 4,327 \\
Muvuti & 2,023 \\
Kimutwa & 3,242 \\
Kiimakimwe & 6766 \\
Mumbuni & 11,652 \\
Katheka Kai & 4,087 \\
Mua Hills & 1,756 \\
Ngelani & 2,503 \\
Mutituni & 3,088 \\
Kalama & 2,434 \\
Lumbwa & 2,820 \\
Kyangala & 1,652 \\
Kola & 2,639 \\
Total Population & 48,989 \\
\hline
\end{tabular}

Source: KNBS, 2009

Table 2: Sample Size

\begin{tabular}{cc}
\hline Name of Location & No of Households \\
\hline Township & 33 \\
Muvuti & 16 \\
Kimutwa & 25 \\
KiimaKimwe & 53 \\
Muumbuni & 91 \\
Katheka Kai & 32 \\
Mua Hills & 14 \\
Ngelani & 19 \\
Mutituni & 24 \\
Kalama & 19 \\
Lumbwa & 22 \\
Kyangala & 13 \\
Kola & 20 \\
Total & 381 \\
\hline
\end{tabular}

Source: Author, 2017

\section{Model specification}

Given that the data from the field was qualitative, the data was coded into binary data implying that binary probabilistic models were fit for 
analysis. More specifically, the probit model was applied. The general representation of the model is specified as follows:

$$
\begin{gathered}
Y=\beta_{0}+\beta_{1} X_{1}+\beta_{2} X_{2}+\ldots \ldots \ldots \ldots . . .+\beta_{K} X_{K}+\varepsilon_{i} \\
\mathrm{Y}=X_{i} \beta+\varepsilon_{i}
\end{gathered}
$$

Where: $Y$ represents increase in household's income levels; Xi represents the various cash transfer programmes and household characteristics; $\beta_{0} \ldots \ldots \beta_{1-k}$ are estimable parameters and $\varepsilon$ is the error term.

From the general representation, of the specific probit model for the study is specified as follows:

$$
Y=\beta_{0}+\beta_{1} X_{1}+\beta_{2} X_{2}++\beta_{3} X_{3}+\beta_{4} X_{4}+\beta_{5} X_{5}+\beta_{6} X_{6}+\beta_{7} X_{7}+\beta_{8} X_{8}+\varepsilon_{i}
$$

Where

$X_{1} \quad$ is cash transfer to older persons

$X_{2} \quad$ is cash transfer to orphans and vulnerable children

$\mathrm{X}_{3} \quad$ is cash transfer to persons with disability

$\mathrm{X}_{4} \quad$ is foreign remittance

$\mathrm{X}_{5-8}$ are household characteristics

$\varepsilon_{\mathrm{i}} \quad$ is error term

The above empirical model equation, represents cash transfers to the older persons, cash transfers to the orphans and vulnerable children, cash transfer to persons with disability, and the remittances by the relatives either abroad or relatives working in the major towns away from rural homes. The other variables (household size, household head, education level of the household head and household economic activity) are the household characteristics.

\section{Sources of Data}

The study utilized the primary data in its analysis. The data was collected using the self-administered structured household questionnaire. The tool was pretested in one of the locations within Machakos Town Council to check on the reliability and the validity of the tool prior to the actual data collection task.

\section{Empirical findings and Discussion}

The data collection tool focused on four variables of social assistance namely, cash transfer to older persons, cash transfer to orphans and other vulnerable children, persons with severe disability cash transfer and remittances outside Machakos County besides other forms of social assistance. 
Generally all the respondents were aware of the types of cash transfer available, with orphans and other vulnerable children cash transfer leading at $44.1 \%$. It is noted that other forms of cash transfer such as bursary, school feeding programmes and hunger safety net are common among the respondents. Table 4.7 and Figure 4.4 depict this information.

Table 3: Cash transfer the household is aware about

\begin{tabular}{ccccc}
\hline & Yes & No & Total & $\begin{array}{c}\text { Sample } \\
\text { size (n) }\end{array}$ \\
\hline Cash transfer to orphans \& Vulnerable Children & 44.09 & 55.91 & 100.00 & 381 \\
School Feeding Programme & 59.32 & 40.68 & 100.00 & 381 \\
Cash transfer to disabled & 9.45 & 90.55 & 100.00 & 381 \\
Cash transfer to elderly & 7.09 & 92.91 & 100.00 & 381 \\
Bursary & 63.78 & 36.22 & 100.00 & 381 \\
Hunger Safety Net & 0.79 & 99.21 & 100.00 & 381 \\
\hline
\end{tabular}
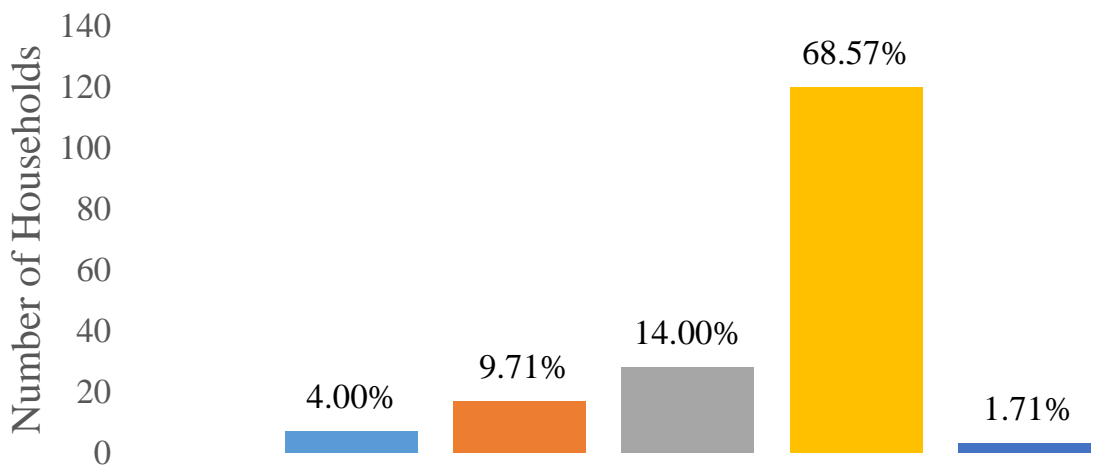

Type of cash transfer received

orphans $\square$ sfp $\square$ elderly $\square$ Bursary $\square$ hsn

Figure 1: Type of cash transfer received

Given that cash transfer was one of the main sources of social assistance particularly in support of children a breakdown of how the assistance was expended indicated that it went to support education as shown in Figure 2. 


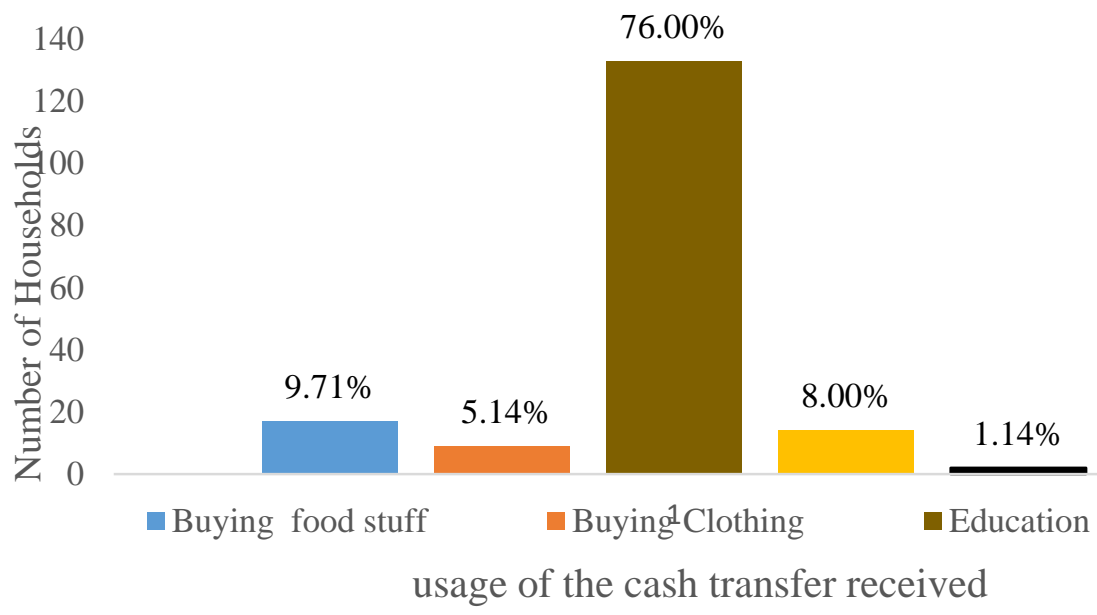

Figure 2: Expenditure category on the cash transfer

Remittances were not signifant among the respondents as only $25.7 \%$ of them recived such assistance which was spent on foodstuff and education. This is shown in Table 4

Table 4: Remittances received and expenditure category

\begin{tabular}{ccccccccc}
\hline & $\mathrm{n}$ & $\begin{array}{c}\text { Buying } \\
\text { food stuff }\end{array}$ & $\begin{array}{c}\text { Buying } \\
\text { clothing }\end{array}$ & Education & $\begin{array}{c}\text { Medical } \\
\text { care }\end{array}$ & $\begin{array}{c}\text { Start } \\
\text { business }\end{array}$ & none & Total \\
\hline No & 283 & 0.00 & 0.00 & 0.00 & 0.00 & 0.00 & 100.00 & 74.28 \\
Yes & 98 & 100.00 & 100.00 & 100.00 & 100.00 & 100.00 & 0.00 & 25.72 \\
Total & 381 & 100.00 & 100.00 & 100.00 & 100.00 & 100.00 & 100.00 & 100.00 \\
\hline Sample size (n) & & 40 & 6 & 32 & 8 & 12 & 283 & 381 \\
\hline
\end{tabular}

In order to investigate the effect of social assistance on improving quality of life of household, cash transfer was used. The probit model was run with the effect of cash transfer on the household income as the dependent variable. However, it's noteworthy that in running this model as per specific objective, other variables were incorporated into the model.

The additional variables are the household characteristics. With regard to the household characteristics, the gender and the highest education level of the household head were included. Also included was marital status and the main economic activity of the household.

From the results, as evidenced by the probit model results in Table 5 it can be concluded that a male headed household is less likely to be well off compared to a female headed household by 0.2400 chances. With regard to education it is noted that a household whose head has college, primary, secondary, university and vocational education is more likely to have better quality of life by $0.2267,0.3120,0.3973,0.0507$ and 0.0053 chances respectively compared to a household whose head has no education at all. However it is observed that the effect of the level of education is not 
significant given that all the probabilities of all levels of education are greater than 5 percent.

Table 5: Probit Model Estimates

\begin{tabular}{|c|c|c|c|c|c|c|c|}
\hline \multicolumn{8}{|c|}{ Robust } \\
\hline & Coef. & $\mathrm{dy} / \mathrm{dx}$ & Std. Err & $\mathrm{z}$ & $\mathrm{P}>|\mathrm{z}|$ & [95\% Con & f. Interval] \\
\hline Male & -0.024 & 0.240 & 0.299 & -0.080 & 0.936 & -0.610197 & 0.561926 \\
\hline College & 0.089 & 0.226 & 0.559 & 0.160 & 0.872 & -1.006329 & 1.186195 \\
\hline Primary & 0.078 & 0.312 & 0.565 & 0.140 & 0.889 & -1.185762 & 1.028005 \\
\hline Secondary & 0.254 & 0.397 & 0.556 & 0.460 & 0.648 & -1.344563 & .8365442 \\
\hline University & 0.063 & 0.050 & 0.624 & 0.100 & 0.920 & -1.160795 & 1.286901 \\
\hline Vocational & 0.113 & 0.005 & 0.755 & 0.150 & 0.881 & -1.593524 & 1.367127 \\
\hline Married & 3.866 & 0.848 & 0.265 & 14.560 & 0.000 & -4.386805 & -3.345861 \\
\hline Never Married & 4.169 & 0.042 & 0.452 & 9.220 & 0.000 & -5.056028 & -3.282795 \\
\hline Separated & 4.034 & 0.018 & 0.565 & 7.130 & 0.000 & -5.143581 & -2.925619 \\
\hline Widowed & 4.145 & 0.082 & 0.393 & 10.530 & 0.000 & -4.917474 & -3.374258 \\
\hline Casual Labour & 0.001 & 0.154 & 0.325 & 0.000 & 0.997 & -0.638076 & 0.635934 \\
\hline Farming & 0.332 & 0.026 & 0.458 & 0.720 & 0.469 & -1.229832 & 0.565753 \\
\hline Retired & 0.740 & 0.021 & 0.721 & 1.030 & 0.305 & -0.673501 & 2.153584 \\
\hline Salaried & 0.134 & 0.285 & 0.264 & 0.510 & 0.611 & -0.383301 & 0.651892 \\
\hline Self Employed & 0.072 & 0.149 & 0.266 & 0.270 & 0.785 & -0.448614 & 0.594094 \\
\hline Peasant & 0.180 & 0.138 & 0.335 & 0.540 & 0.590 & -0.477117 & 0.838828 \\
\hline Income & 0.090 & 0.470 & 0.129 & 0.700 & 0.470 & -0.000025 & 0.000012 \\
\hline Bursary & 1.950 & 0.320 & 0.216 & 8.990 & 0.000 & 1.525078 & 2.375201 \\
\hline Elderly Cash & 2.863 & 0.072 & 0.517 & 5.530 & 0.000 & 1.848648 & 3.878703 \\
\hline Disability Cash & 0.310 & 0.134 & 0.381 & 0.810 & 0.416 & 0.437726 & 1.058032 \\
\hline Hunger Safety & 1.578 & 0.008 & 0.770 & 2.050 & 0.000 & 0.068969 & 3.087940 \\
\hline Orphan Cash & 1.715 & 0.026 & 0.410 & 4.180 & 0.000 & 0.909999 & 2.520050 \\
\hline School Feeding & 1.736 & 0.045 & 0.540 & 3.210 & 0.000 & 0.675984 & 2.796409 \\
\hline Remittances & 1.921 & 1.256 & 0.287 & 6.690 & 0.000 & 1.358581 & 2.483889 \\
\hline Marginalization & -0.296 & 0.824 & 0.228 & -1.300 & 0.094 & -0.744242 & 0.151359 \\
\hline Government Policy & 0.259 & 0.784 & 0.225 & 1.150 & 0.050 & -0.701005 & 0.182744 \\
\hline Corruption & -0.542 & 0.970 & 0.411 & -1.320 & 0.087 & -0.264138 & 1.349683 \\
\hline Constant & 0.917 & 0.632 & 0.862 & 1.060 & 0.288 & -0.773184 & 2.607581 \\
\hline Wald chi' ${ }^{2}(25)$ & $=$ & 981.27 & & Prob & chi ${ }^{2}$ & $=$ & 0.0000 \\
\hline Log pseudo likelihoo & $=$ & -138.234 & & Pseuc & $\mathrm{R}^{2}$ & $=$ & 0.4631 \\
\hline
\end{tabular}

As far as social assistance programmes are concerned and as represented by the cash transfer, the regression results indicate that a household that receives bursary is more likely to be better off than a household that does not receive bursary by 0.32 units. Similarly, the probability of a household that receives cash transfer for orphan and vulnerable children has better quality of life of 0.0267 chances compared to a 
household that receives no social assistance in form of cash transfer, while in the case of cash transfer to the elderly, it is noted that the receipt of cash transfer for elderly is more likely to improve the quality of life by 0.072 chances compared to not receiving any social assistance in form of cash transfer to the elderly. Further the provision of school feeding is more likely to improve the household quality of life by 0.045 percent while that of the hunger safety nets will most likely improve the household quality of life by 0.008 percent. As for the families that receive remittances from their relatives working outside home they are more likely to have a higher quality of life by 1.256 chances compared to households that do not receive any remittances from relatives.

This picture depicts a case of extreme poverty in the catchment area and supporting the view by Hulme, et al (2003) where households lack both income and assets and therefore suffering from interrelated chronic deprivation including hunger and malnutrition, poor health, limited education and marginalization or/and exclusion. It is also noted that under pro-poor programmes this aspect of chronic deprivation features. This is why other forms cash transfer such as bursary, school feeding programmes and hunger safety net are found to be significant among the households.

\section{Concluding remarks and policy implications}

From the results in this study it is clear that the cash transfer to the elderly, cash transfer to orphans, cash transfer for hunger safety net, cash transfer for bursary, and remittances significantly influence the quality of life among the households in Machakos County. This is further justified by the fact that the $\mathrm{p}$ - values of all the cash transfers are less than 5 percent significance level. However, for the cash transfer to disabled, the $\mathrm{p}-$ value is greater than 5 percent. The findings are consistent with the findings by Hulme, et al (2003).

From the study, cash transfers to orphans contribute to improve quality of life through increased economic empowerment from addition income. The additional income is used for purchase of food stuff thus reducing food poverty in the recipient households. Some of the households direct such transfers to payment of medical bills, payment of school fees while others start income generating projects hence posterity in terms of additional future income. Therefore income poverty is reduced in the long run if the cash transfers are used in investing in income generating projects. In terms of cash transfers to the elderly, the significant positive effect on the households welfare implies that since the elderly are dependants, with such cash transfers the level of dependence on the working members of the household is reduced. As such the working household members are capable of using the income meant to support the elderly on other alternative 
expenditures such as investment in productive venture or even consumption expenditure that improve on the household's welfare.

On the school feeding programmes, the positive significant effect on the household welfare could be indirect. First is the increased school retention rate which positively impact on the literacy levels in the long run. This in turn comes with increased productivity through improved skills development via the education system. Secondly, the school feeding programme impacts the household's quality of life in that the food expenditure for the household is lowered and therefore the income can be reallocated towards other consumption within the household. Similar effects would be expected for the hunger safety nets which would be core in reducing food poverty within the households.

On the recommendation front, the study posits that social assistance programmes have proved to be useful in reducing poverty and in turn improve quality of life of households. The components of social assistance that have significant effect on the reduction of poverty are cash transfer to the elderly, cash transfer to orphans and vulnerable children, cash transfer for hunger safety nets, cash transfer for bursary and remittances from residents in diaspora as evidenced in the study. Therefore, the county and national governments should focus on these components of social assistance if poverty levels of households are to be reduced as advocated by the international community through SDG. Caution however should be taken in the implementation of such programmes as corruption and marginalization can divert these programmes from the intended purpose. Further awareness and sensitization of the availability of such funds need to be created with the focus being towards advising the recipients to utilize these resources efficiently for maximum welfare. The study also recommends that fairness be enhanced in vetting the households who qualify to receive the government cash transfers to ensure that the funds are directed to the intended recipients. To this a clear criteria of vetting beneficiaries should be put in place in order to avoid political leverage, favouritism, clanism, nepotism among others, as these will only compromise on the fairness when it comes to selection of the beneficiaries thus jeopardizing the achievement of the intended effects of such cash transfers.

\section{References:}

1. African Union (2013), Agenda 2063: The Africa we Want, Roosevelt Street Addis Ababa, Ethiopia Roosevelt Street.

2. Barrientos A. and J. De Jong, (2006). "Reducing Child Poverty with Cash Transfers: A Sure Thing?”. Development Policy Review, 24(5), 537-552 
3. Buch, C. and A. Kuckulenz, (2002). "Worker Remittances and Capital Flows to Developing Countries," Discussion Paper No. 0431, Mannheim: Centre for European Economic Research.

4. De la Brière B. and L. Rawlings. (2006). "Examining Conditional Cash Transfer Programs: A Role for Increased Social Inclusion?”. World Bank, Social Protection Discussion Paper No. 0603, Washington D.C.

5. De Janvry, Alain, Elisabeth Sadoulet and Renos Vakis. (2008). Protecting Vulnerable Children from Uninsured Risks: Adapting Conditional Cash Transfer Programs to Provide Broader Safety Nets. France: Fondation Pour Le S Étude S Et Recherche S Sur Le Développement Inte Rnational.

6. Dlamini, A. (2007). A review of social assistance grants in Swaziland: a CANGO/RHVP case study on public assistance in Swaziland. Report written for the Regional Evidence Building Agenda (REBA) of the Regional Hunger and Vulnerability Programme (RHVP), Johannesburg.

7. Enrique L, V. (2008). Conditional Cash Transfers as Social Policy in Latin America: An Assessment of their Contributions and Limitations. Annual Review of Sociology, 34: 475-499.

8. Gustavo Nigenda \& Luz María González-Robledo (2005), Lessons offered by Latin American cash transfer programmes, Mexico's Oportunidades and Nicaragua's SPN. Implications for African countries, Centre for Social and Economic Analysis Mexican Health Foundation.

9. Heinrich C. (2007). "Demand and Supply-Side Determinants of Conditional Cash Transfer Program Effectiveness”. World Development 35(1) (p.121- 143).

10. HelpAge, (2006). Social cash transfers for Africa a transformative agenda for the 21st century

11. Hulme, D. \& Shepherd, A. (2003). Conceptualizing Chronic Poverty, World Development, 31, 3-23.

12. Kenya Integrated Household Budget Survey (2006), Kenya National Bureau of Statistics, Government Press, Nairobi, Kenya.

13. Kenya population and census Report, (2010), Kenya National Bureau of Statistics, Government Press, Nairobi, Kenya.

14. Kenya the National Gender and Equality Commission (2008) Reports, Nairobi, Kenya.

15. Maluccio J. and Flores. R. (2005). "Impact Evaluation of the Pilot Phase of the Nicaraguan Red de Protección Social”. IFPRI, Research Report No.141. Washington, D.C. 
16. Organisation for Economic Corporation and Development, (2009). The role of employment and social protection: making economic growth more pro-poor. Policy Statement, DAC High-level meeting.

17. Ratha, D., (2003). "Workers' Remittances: An Important and Stable Source of External Development Finance," (Chapter 7) in Global Development Finance: Striving for Stability in Development Finance, Washington, DC: World Bank, pp. 157-175.

18. Samson M., Van N, I. and K. Mac Quene. (2006). "Designing and Implementing Social Transfers Programmes”. Economic Policy Research Institute. Cape Town.

19. Tegemeo Institute of Agricultural Policy and Development, (2009). Rural Incomes, Inequality and Poverty Dynamics in Kenya WPS $30 / 2008$

20. Todaro, P \& Smith, C. (2011). Economic development. Boston: Pearson Addison Wesley.

21. United Nations Development Programme, (2005). Human Development Report, New York. 